\title{
Sorption of heavy metals by laterite from Vinh Phuc and Hanoi, Vietnam
}

\author{
Nghiên cứu khả năng hấp phụ kim loại nặng của laterit đá ong khu vục tỉnh \\ Vĩnh Phúc và Hà Nội, Việt Nam \\ Research article
}

Nguyen, Hoang Phuong Thao ${ }^{1}$; Nguyen, Thi Hoang Ha ${ }^{2}$; Bui, Thi Kim Anh ${ }^{3}$

${ }^{1}$ Sea and Island Research Center, VNU University of Science, 334 Nguyen Trai, Hanoi, Vietnam, ${ }^{2}$ Department of Geoenvironment, VNU University of Science, 334 Nguyen Trai, Hanoi, Vietnam; ${ }^{3}$ Institute of Environmental Technology, Vietnam Academy of Science and Technology, 18 Hoang Quoc Viet, Hanoi, Vietnam

\begin{abstract}
This study was carried out to evaluate the sorption capacity of $\mathrm{Pb}, \mathrm{As}, \mathrm{Cd}, \mathrm{Zn}$, and $\mathrm{Mn}$ by laterite from Tam Duong District (Vinh Phuc Province) and Thach That District (Hanoi City). Laterite samples were exposed to different initial concentrations of heavy metals in solutions $(2.5,5.0,10,20$, and $50 \mathrm{mg} / \mathrm{l}$ ) at $\mathrm{pH}=5.5$ during 24 hours. The results demonstrated that sorption capacity of heavy metals was in the following order: $\mathrm{Pb}>\mathrm{As}>\mathrm{Cd}>\mathrm{Zn}>\mathrm{Mn}$. The highest sorption capacity of $\mathrm{Pb}, \mathrm{As}$, $\mathrm{Cd}, \mathrm{Zn}$, and Mn of laterite from Tam Duong was $1553,756,397,281$, and $143 \mathrm{mg} / \mathrm{kg}$, respectively and the highest removal efficiency was $94,76,70,56$ and $37 \%$. The results indicated that laterite from Tam Duong District showed lower sorption capacity than that from Thach That District. The disparity sorption capacity of $\mathrm{Pb}, \mathrm{As}, \mathrm{Cd}, \mathrm{Zn}, \mathrm{Mn}$ between laterite from Thach That and Tam Duong was 10.3-11.6, 11.9-17.9, 11.5-13.7, 9.5-17.6, and 11.1-14.3\%, respectively. Laterites from Tam Duong and Thach That are a promising environmental material which can be used in the removal of heavy metals from wastewater.
\end{abstract}

Nghiên cứu này được thục hiện nhằm đánh giá khả năng hấp phu $\mathrm{Pb}, \mathrm{As}, \mathrm{Cd}, \mathrm{Zn}$, và Mn bởi laterit đá ong khu vưc huyện Tam Dương (Vĩnh Phúc) và huyện Thạch Thất (Hà Nội). Mẫu đá ong được tiến hành thi nghiệm trong các dung dịch có hàm luợng kim loại nặng ban đầu khác nhau $(2,5 ; 5,0$; 10; 20 và $50 \mathrm{mg} / \mathrm{l}$ ) tai $\mathrm{pH}=5,5$ trong 24 giò̀. Kết quả nghiên cứu cho thấy mức độ hấp phu kim loại nạng bởi laterit đá ong lần luoọt là $P b>A s>C d>Z n>M n$. Dung luợng hấp phu $P b, A s, C d, Z n$ và Mn cao nhất của laterit Tam Duơng làn luợt là 1553, 756, 397, 281 và $143 \mathrm{mg} / \mathrm{kg}$ và hiệu suất hấp phu cao nhất lần lươt là 94, 76, 70, 56 và 37\%. Dung luợng hấp phu kim loại nặng của laterit huyện Tam Duơng thấp hơn khu vục huyện Thạch Thất. Sụ chênh lệch về dung luợng hấp phu Pb, $\mathrm{As}, \mathrm{Cd}$, Zn và Mn giũa laterit Thạch Thất và laterit Tam Duơng lần luợt là 10,3-11,6; 11,9-17,9; 11,513,7; 9,5-17,6 và 11,1-14,3\%. Kết quả nghiên cứu buớc đầu cho thấy đá ong khu vục huyện Tam Duơng và Thạch Thất là vật liệu hấp phu tiềm năng phục vu ưng dụng trong xủ lý nước thải bị nhiếm kim loại nặng.

Keywords: heavy metals, removal, laterite, solutions, sorption

\section{Introduction}

Water pollution by heavy metals has been a major considered issue in recent years. A variety of chemical - physical technologies have been applied to deal with the removal of these metals from water, including precipitation (Gunatilake, 2015), ion exchange (Gaikwad et al., 2010), electrocoagulation (Turdean and Popescu, 2013), and biological processes (Dhokpande and Kaware, 2013). Of which, adsorption of heavy metals from solutions has emerged as a cost-effective and high removal efficiency technology. Several natural materials have been reported for treatment wastewater, including kaolinite (Adebowale et al., 2005), sludge (Genc et al., 2003; Doan and Nguyen, 2011), diatomite (Al-degs et al., 2001; Li et al., 2009), and laterite (Yu et al., 2008).

Laterite is the final product in the process of chemical weathering in the humid tropics with the accumulation of $\mathrm{Fe}$ and $\mathrm{Al}$ oxides and hydroxides. In Asia, the laterite is 
very popular in China, India, Bangladesh, Vietnam, and Indonesia. In Vietnam, laterite is widely distributed in the north and central highlands. Laterite from Hanoi City was reported to have high sorption capacity of heavy metals such as $\mathrm{Pb}, \mathrm{As}, \mathrm{Zn}, \mathrm{Ni}, \mathrm{Mn}, \mathrm{Cu}, \mathrm{Co}$, and $\mathrm{Cd}$ from solutions (Tran et al., 2004; Nguyen, 2010). However, no previous research has assessed the sorption of heavy metals by laterite from Vinh Phuc Province. The objective of this research is to assess the sorption capacity of laterite from Vinh Phuc Province in comparison with laterite from Hanoi City.

\section{Materials and methods}

\subsection{Sampling}

Laterite samples were collected at Thanh Van Commune, Tam Duong District, Vinh Phuc Province and Binh Yen Commune, Thach That District, Hanoi City. The laterite sample in Hanoi was taken at the same site as reported by Nguyen (2010) for comparison.

\subsection{Heavy metals preparation}

Five metals ( $\mathrm{Mn}, \mathrm{Zn}, \mathrm{Cd}, \mathrm{Pb}$, and $\mathrm{As}$ ) were added as standard solutions $\left(\mathrm{Pb}\left(\mathrm{NO}_{3}\right)_{2}, \mathrm{Zn}\left(\mathrm{NO}_{3}\right)_{2}, \mathrm{Mn}\left(\mathrm{NO}_{3}\right)_{2}, \mathrm{Cd}\left(\mathrm{NO}_{3}\right)_{2}\right.$ and $\mathrm{Na}_{2} \mathrm{HAsO}_{4}$ ). The reagents were dissolved in Milli-Q water to obtain the desired contamination levels. Then the solutions were adjusted to $\mathrm{pH} 5.5$ with $\mathrm{NaOH}$ and $\mathrm{HNO}_{3}$.

\subsection{Experiment design}

\subsection{1 pHPZC}

Two grams of each laterite sample were placed in boxes containing $100 \mathrm{ml}$ deionized water and $\mathrm{NaNO}_{3} 0.01 \mathrm{M}$. pHi was adjusted by $\mathrm{NaOH}$ or $\mathrm{HNO}_{3}$ at $\mathrm{pH} 3,4,5,6,7$ and 8 . The samples were shaken for 24 hours (120 turns/min). All of laboratory experiments were repeated in duplicate. The $\mathrm{pH}_{\mathrm{PZC}}$ values were determined by the equation 1.1 :

$$
\Delta \mathrm{pH}_{\mathrm{PZC}}=\mathrm{pHi}-\mathrm{pHf}
$$

Where $\mathrm{pHi}$ and $\mathrm{pHf}$ are $\mathrm{pH}$ of solutions before and after 24 hour-shaking.

The intersection of the trendline with the horizontal axis at the point $\Delta \mathrm{pH}=0$ determined $\mathrm{pH}_{\mathrm{PZC}}$.

\subsubsection{Sorption of heavy metals}

Two grams of laterite sample were placed in $100 \mathrm{ml}$ of water containing 2.5, 5.0, 10, 20 and $50 \mathrm{mg} / 1$ of each metal ( $\mathrm{Mn}, \mathrm{Zn}, \mathrm{Cd}, \mathrm{Pb}$, and $\mathrm{As}$ ). The samples were exposed to the solutions for 24 hours under shaking condition (120 turns/min). All of the laboratory experiments were repeated in duplicate.

The sorption capacity $(q e)$ is calculated by the following equation (1.2):

$$
q e=\frac{(\mathrm{Co}-\mathrm{Ce}) \mathrm{V}}{m}
$$

Where qe, Co, Ce, $\mathrm{m}$, and V are sorption capacity ( $\mathrm{mg} / \mathrm{kg}$ ), initial metal concentrations in water $(\mathrm{mg} / \mathrm{l})$, metal concentrations in water at equilibrium $(\mathrm{mg} / \mathrm{l})$, mass of material $(\mathrm{g})$, and solution volume $(\mathrm{ml})$, respectively.

The removal efficiency, which can be used to assess the potential of laterite for wastewater treatment, is calculated by the equation 1.3 :

$$
\text { Removal efficiency }=\frac{(\boldsymbol{C o}-\boldsymbol{C e}) \mathbf{1 0 0} \%}{\boldsymbol{C o}}
$$

Where Co and Ce are initial metal concentrations in water $(\mathrm{mg} / \mathrm{l})$ and metal concentrations in water at equilibrium $(\mathrm{mg} / \mathrm{l})$, respectively.

\subsection{Analytical methods}

Samples were dried by NIIVE OVER KD200 temperature at $80-105^{\circ} \mathrm{C}$ and crushed by Equipment Manufacurer MRC at the Faculty of Geology, VNU University of Science, Vietnam National Univesity, Hanoi. Mineral compositions of the laterite samples were determined using the X-Ray Diffraction (XRD - Siemens D5005) at the Faculty of Physics, VNU University of Science. Particle Charge Detector (PCD - Mütek PCD-05) was performed for determination of surface charge density at the Faculty of Environmental Sciences, VNU University of Science. Elemental analyses of water samples were performed by Atomic Absorption Spectroscopy (AAS - 280FS, VGA77, Agilent) at the Key Laboratory of Geoenvironment \& Climate change Response (GEO-CRE), Vietnam National University, Hanoi.

\section{Results and discussion}

\subsection{Characteristics of laterite}

The results of mineral compositions (XRD) showed high percentage of kaolinite and goethite in laterite (Table 1). The percentage of goethite and kaolinite in laterite from Vinh Phuc Province was 15\% and 36\%, respectively; that in laterite from Hanoi City was $42 \%$ and $40 \%$ (Table 1). The lower proportion of goethite and kaolinite in laterite from Vinh Phuc Pronvince than that in Hanoi City may indicate the sorption capacity. The displacement of $\mathrm{H}^{+}$ion from the edge site of kaolinite and the metals sorption are usually accompanied. The result of surface charge density (PCD) of laterite from Vinh Phuc Province demonstrated lower values than that from Hanoi City (Table 2).

The zero charge points of laterite from Hanoi and Vinh Phuc were obtained at $\mathrm{pH} 4.2$ and 5.2, respectively. The results suggested that $\mathrm{pH}_{\mathrm{PZC}}$ of laterite from two provinces was lower than $\mathrm{pH}$ value set in the present experiment $(\mathrm{pH}=5.5)$, Therefore, the two materials tended to adsorb cations such as $\mathrm{Mn}^{2+}, \mathrm{Zn}^{2+}, \mathrm{Pb}^{2+}$, and $\mathrm{Cd}^{2+}$ (Nguyen, 2010). 
Table 1. Minerals composition of laterite from Vinh Phuc and Hanoi

\begin{tabular}{lrrrrrr} 
Minerals & Quartz & Kaolinite & Illite & Goethite & Hematite & Magnetite \\
\hline Vinh Phuc & $39 \%$ & $36 \%$ & $2 \%$ & $15 \%$ & $7 \%$ & $1 \%$ \\
Hanoi & $9 \%$ & $40 \%$ & $3 \%$ & $42 \%$ & $3 \%$ & --
\end{tabular}

Table 2. Surface charge density of laterite from Vinh Phuc and Hanoi

Minerals
$\mathrm{Q}\left(\mathrm{mmol}_{\mathrm{c}(-)} \mathrm{Kg}^{-1}\right)$
.2 Sorption of heavy metals by laterite from
inh Phuc Province

The sorption capacity of laterite from Vinh Phuc Province was proportional to initial concentrations of heavy metals in solutions. The highest sorption capacity of $\mathrm{Pb}, \mathrm{As}, \mathrm{Cd}$, $\mathrm{Zn}$, and Mn by laterite from Vinh Phuc was 1553, 756, 397, $281,143 \mathrm{mg} / \mathrm{kg}$, respectively (Figure 1) which was obtained at initial concentrations heavy metals of $50 \mathrm{mg} / \mathrm{l}$. The highest removal efficiencies of $\mathrm{Pb}, \mathrm{As}, \mathrm{Cd}, \mathrm{Zn}$ and $\mathrm{Mn}$ were 94, 76, 70, 56 and 37\%, respectively (Figure 2). The sorption capacity of heavy metals by laterite was in the following order: $\mathrm{Pb}>\mathrm{As}>\mathrm{Cd}>\mathrm{Zn}>\mathrm{Mn}$. This result is possibly due to the effect of cation radius in which larger radius indicates a smaller charge density and weakly hydrated cations. Cations with large charge density have strong resistance to the electrostatic force. Therefore, $\mathrm{Mn}$ is more difficult to be adsorbed than other metals. The radius of metal cations in descending order was $\mathrm{Pb}\left(1.2 \mathrm{~A}^{0}\right)>\mathrm{Cd}$ $\left(0.97 \mathrm{~A}^{0}\right)>\mathrm{Zn}\left(0.74 \mathrm{~A}^{0}\right)>\operatorname{Mn}\left(0.67 \mathrm{~A}^{0}\right)$. Arsenic can be adsorbed by the positive surface of the crystal structure of goethite. In addition, arsenic is also fixed in goethite according to following equation (Nguyen, 2014):

$$
\mathrm{Fe}-\mathrm{OH}+\mathrm{AsO}_{4}{ }^{2-}+\mathrm{H}=\mathrm{Fe}-\mathrm{OAsO}_{3}{ }^{2-}+\mathrm{H}_{2} \mathrm{O}
$$

Metal sorption capacity of laterite was tested to fit Langmuir and Freundlich models (Sparks, 2003) for further understanding of sorption mechanism. The results demonstrated that the sorption capacity of $\mathrm{Pb}, \mathrm{As}, \mathrm{Cd}$, and $\mathrm{Zn}$ by laterite from Vinh Phuc Province was well fitted to the $\mathrm{C}$ linear type (Freundlich isotherm) (Sparks, 2003) with the correlation coefficient of $0.93,0.89,0.97$, and 0.99 , respectively. This result indicates that both adsorption and precipitation processes occurred simultaneously in the experimental solutions. In addition, experimental data of Mn on laterite from Vinh Phuc Province matched with L-type (Langmuir isotherm) (Sparks, 2003) with correlation coefficient of 0.99 which indicate that sorption capacity was inversely proportional to the initial concentrations of $\mathrm{Mn}$ in the experimental solutions. However, the increasing trend of sorption capacity with an increase in initial concentrations of heavy metals in solutions (Figure 1) indicates the need for further study on determination of sorption at equilibrium.
Quartz

$39 \%$

Kaolinite

\subsection{Comparison of sorption of heavy metals by laterite from Vinh Phuc and Hanoi provinces}

The highest sorption capacity of $\mathrm{Pb}, \mathrm{As}, \mathrm{Cd}, \mathrm{Zn}$ and $\mathrm{Mn}$ by laterite from Ha Noi Province was 1806, 1023, 503, 268, and $228 \mathrm{mg} / \mathrm{kg}$, respectively (Figure 1). The highest removal efficiency of $\mathrm{Pb}, \mathrm{As}, \mathrm{Cd}, \mathrm{Zn}$ and $\mathrm{Mn}$ by laterite from Ha Noi was 98, 96, 84, 61, and 53\%, respectively (Figure 2). These results indicated that laterite from Vinh Phuc showed lower sorption capacity and removal efficiency than that from Hanoi (Figure 1,2). The disparity adsorption capacity of $\mathrm{Pb}, \mathrm{As}, \mathrm{Cd}, \mathrm{Zn}$, and $\mathrm{Mn}$ between laterite from Hanoi and Vinh Phuc was 10.3-11.6, 11.9-17.9, 11.5$13.7,9.5-17.6$, and $11.1-14.3 \%$, respectively. These results are possibly due to the higher percentage of goethite and kaolinite, higher values of surface charge density (PCD) of laterite from Hanoi than those from Vinh Phuc (Table 1, 2).

High sorption capacity and removal efficiency of heavy metals by laterite from Hanoi was in accordance with the results reported by Nguyen (2010). The difference in metal sorption by laterite from Thach That District, Hanoi City in this study than that in report of Nguyen (2010) may be due to the percentage of goethite $(42 \%)$ and kaolinite $(25 \%)$. In addition, the removal efficiency of heavy metals by laterite from Hanoi and Vinh Phuc was higher than that reported in bauxite, bentonite and zeolite (Naseem and Tahir, 2001; Le and Phan, 2008, Nibou et al., 2010; Nguyen, 2010).

\section{Conclusions}

Laterite from Tam Duong District, Vinh Phuc Province has a potential for sorption of heavy metals from solutions. The highest sorption capacity of $\mathrm{Pb}, \mathrm{As}, \mathrm{Cd}, \mathrm{Zn}$, and $\mathrm{Mn}$ by laterite from Tam Duong District was 1553, 756, 397, 281, and $143 \mathrm{mg} / \mathrm{kg}$, respectively. The sorption capacity and removal efficiency of heavy metals by laterite from Tam Duong District were lower than those from Thach That District, Hanoi City, possibly due to differences in composition of goethite and kaolinite. The disparity sorption capacity of $\mathrm{Pb}, \mathrm{As}, \mathrm{Cd}, \mathrm{Zn}$, and $\mathrm{Mn}$ between laterite from Thach That and Tam Duong was 10.3-11.6, 11.9-17.9, $11.5-13.7,9.5-17.6$, and $11.1-14.3 \%$, respectively. 

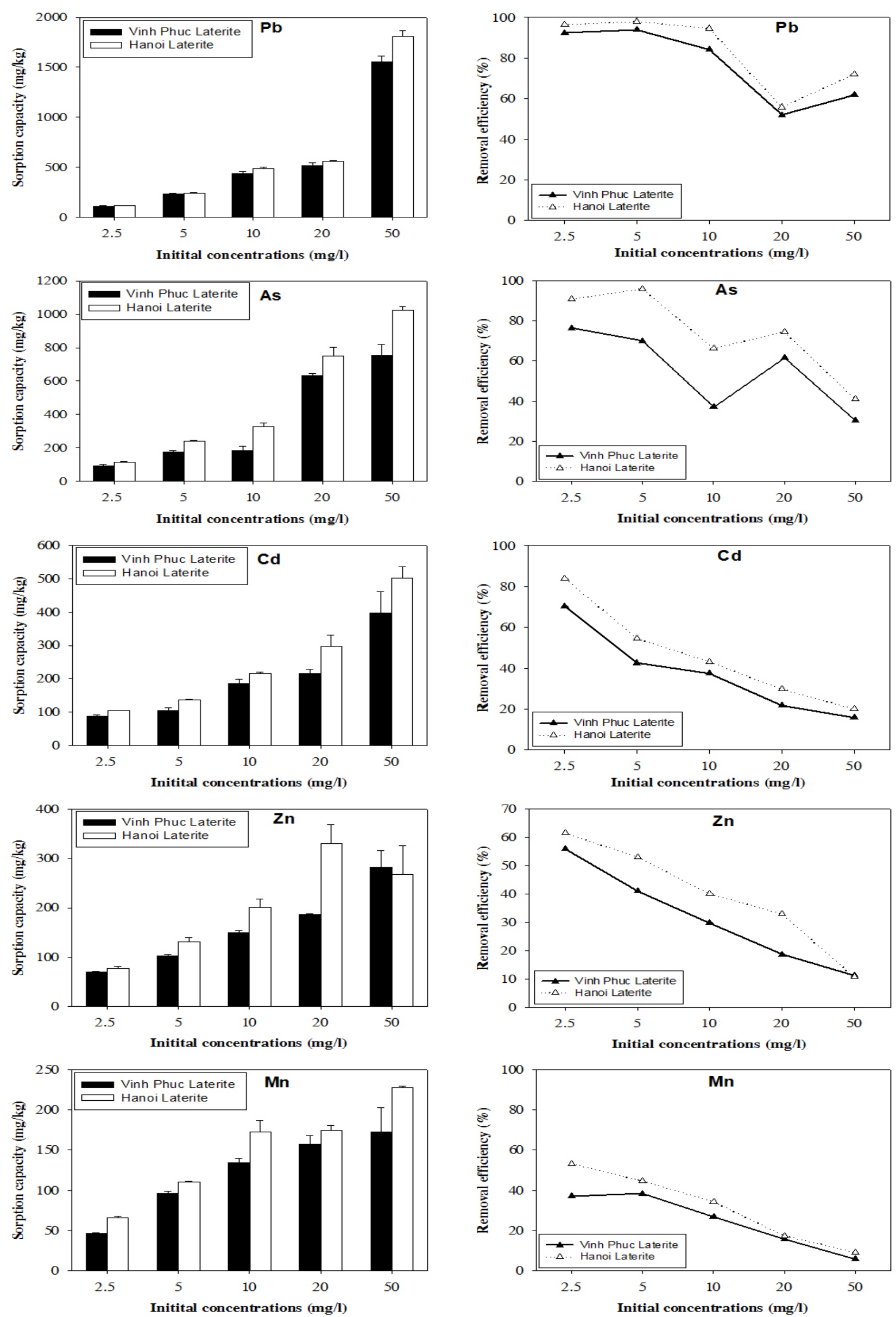

Figure 1. Sorption capacity of $\mathrm{Pb}, \mathrm{As}, \mathrm{Cd}, \mathrm{Zn}$, and $\mathrm{Mn} \quad$ Figure 2. Removal efficiency of $\mathrm{Pb}, \mathrm{As}, \mathrm{Cd}, \mathrm{Zn}$, and $\mathrm{Mn}$ by laterite from Vinh Phuc and Hanoi by laterite from Vinh Phuc and Hanoi 
Acknowledgements: This research was supported by the National Science and Technology Program for Sustainable Development of Vietnam' Northwest Region (KHCN-TB.02C/13-18).

\section{References}

[1] Adebowale, K.O., Unuabonah, I.E., \& Olu-Owolabi, B.I. (2006). The effect of some operating variables on the adsorption of lead and cadmium ions on kaolinite clay. Journal of Hazardous Materials, 134 (1), 130 139.

[2] Al-degs, Y., Khraisheh, M.A.M. \& Tutunji, F. (2001). Sorption of lead ions on diatomite and manganese oxides modified diatomite. Water Research, 35(15), 3724-3728.

[3] Dhokpande, S. R., \& Kaware, J. P. (2013). Biological methods for heavy metal removal-A review. International Journal of Engineering Science and Innovative Technology, 2(5), 304-309.

[4] Doan, D.H. \& Nguyen, T.M. (2011). Study of Zn(II) on Bao Loc modified- granular bauxite mining tail by column experiment. Vietnam Journal of Earth Science, 33, 591-598.

[5] Gaikwad, R. W., Sapkal, V. S., \& Sapkal, R. S. (2010). Ion exchange system design for removal of heavy metals from acid mine drainage wastewater. Acta Montanistica Slovaca, 15(4), 298-304.

[6] Genc, H., Tjell, J. C., McConchie, D., \& Schuiling, O. (2003). Adsorption of arsenate from water using neutralized red mud. Journal of Colloid and Interface Science, 264(2), 327-334.

[7] Gunatilake, S. K. (2015). Methods of Removing Heavy Metals from Industrial Wastewater. Journal of Multidisciplinary Engineering Science Studies, 1 (1), 12-18.

[8] Le, T.H. \& Phan, U.C. (2008). Study on modified Thuan Hai bentonite and removal $\mathrm{Mn}^{2+}$ in aqueous solutions. Journal of Technology and Science, The University of Danang 03(26).

[9] Li, E., Zeng, X., \& Fan, Y. (2009). Removal of chromium ion (III) from aqueous solution by manganese oxide and micro emulsion modified diatomite. Desalination, 238(1), 158-165.

[10] Naseem, R., \& Tahir, S. S. (2001). Removal of Pb (II) from aqueous/acidic solutions by using bentonite as an adsorbent. Water Research, 35(16), 3982-3986.

[11] Nguyen, T. M. (2010). Research adsorption product manufactured on the basis of natural mineral materials as basalt, laterite, clay to treatment wastewater polluted with heavy metals and arsenic. KC02.25/0610.

[12] Nguyen, T.H.N. (2014). Removal of arsenic in wastewater by weathered tropical soils. Water Resources University.

[13] Nibou, D., Mekatel, H., Amokrane, S., Barkat, M., \& Trari, M. (2010). Adsorption of $\mathrm{Zn}^{2+}$ ions onto $\mathrm{NaA}$ and $\mathrm{NaX}$ zeolites: kinetic, equilibrium and thermodynamic studies. Journal of Hazardous Materials, 173(1), 637-646.

[14] Sparks, D. L. (2003). Environmental soil chemistry. Academic press.

[15] Tran, H.C., Nguyen, P.T., Phuong, T. (2004). Activation of thermal denaturated clay and laterite formed arsenic sorption material for treatment of arsenic in drinking water, Vietnam Journal of Science, 1.

[16] Turdean, G. L., \& Popescu, I. C. (2013). Electrochemical method for heavy metals detection by inhibition of acetyl cholinesterase immobilized on pt-nanoparticles modified graphite electrode. Proceedings of the 16th International Conference on Heavy Metals in the Environment, Rome, Italy.

[17] Yu, X., Zhu, L., Guo, B., \& He, S. (2008). Adsorption of mercury on laterite from Guizhou Province, China. Journal of Environmental Sciences, 20(11), 13281334. 